\title{
WHO ARE AMERICANS? ANALYSIS OF OBAMA AND TRUMP'S POLITICAL SPEECHES ON IMMIGRATION
}

\author{
Sonia Tinshe, *Junaidi \\ *Corresponding Author \\ English Studies Program, Universitas Indonesia \\ junaidi@ui.ac.id
}

\begin{abstract}
Immigration has been a crucial discussion in the American politics ever since the nation was still writing its constitution. Seeing how immigrants have shaped the American society, it is important to see how they are perceived, as minorities, by significant political figures, such as the president. The objective of this paper is to understand the ideology behind Obama and Trump's political speeches about immigration, as well as its relevance to the political discourse and social context in America. Five political speeches from Obama (2009-2014), as well as two political speeches from Trump (2016-2017) are analyzed, as the primary data, using Critical Discourse Analysis, particularly Fairclough's (1993) three-dimensional framework. The finding shows that Obama's and Trump's ideology on immigration is related with their idea of the immigrant's identity in American society. It is shown through their word choice, such as pejorative adjective, and the theme related with the issue of immigration. Seen from the political discourse, the speeches are showing perceived superiority that the presidents have over immigrants. Moreover, from the social perspective, it dehumanizes and reduces the identity of immigrants.
\end{abstract}

Keywords: Critical Discourse Analysis, American identity, ideology, immigration, political speech

\section{INTRODUCTION}

"Give me your tired, your poor,

Your huddled masses yearning to breathe free,

The wretched refuse of your teeming shore.

Send these, the homeless, tempest-tost to me,

I lift my lamp beside the golden door!"

The New Colossus, Emma Lazarus (1883)

The sonnet 'The New Colossus' by Emma Lazarus (1883) gives a perfect portrayal of the American's attitude towards immigrants. They welcome the immigrants ("Send these, the homeless, tempest-tost to me") while simultaneously condemning them using harsh portrayal ("The wretched refuse of your teeming shore") (Higham, 1984). This attitude could also be seen in the U.S. constitution. For instance, Schlesinger, (1971) explains that in 1798, the Federalist Party, dominated by aristocratic sympathies, passed the Alien and Sedition Acts and the Naturalization Law. They were afraid that immigrants, or as they referred to as "aliens", would pollute the American constitution, as they were giving "a democratizing influence on American life." However, the legislation did not survive at the end. Meanwhile, Weisberger (1994) argues that the United States "was created by settlers who arrived from elsewhere, who deliberately and calculatedly invited and urged others to follow them, and who encouraged the process in 
ways that were unique". This dual attitude towards immigrants is still prominent until recent years.

By 2016, more than 43.7 million immigrants resided in the United States with an estimated of 11 million unauthorized immigrants in 2014 (The Migration Policy Institute, 2018). Mexico and Central America accounted for most unauthorized immigrants with an estimated number of 7.9 million people in total. While some of the immigrants have education, $29 \%$ of the overall immigrant population is lacking a high school diploma. This led to the popular notion that immigrants are ruining American economy and society. As quoted from Gold (2009), David Stoll, an American anthropologist, suggests that the immigrants are threatening the national unity.

"Because contemporary immigrants are non-European, uneducated, poor, motivated by financial gain and uninterested in joining the moral community of American society, their presence threatens national unity, obscures American citizens' obligations to one another and will shortly change the US into a minority-majority society" (Gold, 2009)

This problematic attitude towards the immigrants is one of the reasons why the American society is torn apart. However, the dual attitude towards immigrants comes not only from the public, but also from significant figures in the U.S. politics.

In 2014, President Barack Obama delivered a speech about the new immigration policy that will be implemented. In his speech, he talks about how "deportations of criminals" are going to be the focus of the new policy. Similar to Obama's speech, Donald Trump also addressed his future plan for immigration in his rally speech in Phoenix, Arizona on 2016. He states that "countless innocent American lives have been stolen because our politicians have failed in their duty to secure our borders and enforce our laws". He outspokenly says that he wanted to build a wall to prevent illegal immigrants, especially from Mexico, to enter America. Seeing how immigration has shaped the American society since it was built up till now, it is important to see how immigration is perceived by these powerful political figures, as the president. Moreover, the ideology behind Obama and Trump's speeches could also shed some lights of how immigrants are positioned in the American society.

Fairclough and Wodak (1997) argue that language can be used as a form of action to change the world, while simultaneously become a form of action that is connected socially and historically with other social aspects. Moreover, Threadgold (1989) also argues that texts are never ideology free, objective, nor can they be separated from the social realities. Therefore, political discourse can be seen in almost every text. In political discourse, Critical Discourse Analysis (CDA) sees the notion of discursive practices as a "conceptualized" relation between power and dominance in the society and how it relates to control the production and the reproduction of text in a particular culture (Fairclough, 1995). Because it considers the power dominance in a social and cultural context, CDA is often used to analyze political discourse. Not only CDA analyses the language factors used in a text, it also considers the social and cultural context of a text.

Analysis of political speeches, particularly on the study case of Barack Obama, has been discussed a few times. Boyd (2009) analyzes the discourse about race and 
identity behind Barack Obama's speeches. The result shows that the speeches, like any other historically significant speeches, are influenced by the current social practice, as well as influencing it. Feng and Liu (2010) analyze the interpersonal meaning behind Obama's $100^{\text {th }}$ day speech. They find out that Obama delivered his interpersonal meaning through a few strategies, and used them to express his political purpose which is to gain trust from his audience. Mohammadi and Biria (2012) compare political speeches from two former presidents of the United States, Obama and Bush. They find a relation between language, power, and ideology by analyzing the rhetorical devices used and the discursive characteristic of the speeches. Krampa and Sarfo (2013) also find that both of the former presidents projected terrorism in a very negative way. They believe that this is the sign of nationalism that Obama and Bush wanted to convey in their speeches.

While there are a lot of studies that discuss about Obama and Bush political speeches, it is still hard to find ones that compares Obama and Trump's political speeches. Moreover, these studies are mostly talking about the linguistic strategy that is used and its purpose. Thus, this study will compare Obama and Trump's political speeches and look into it beyond the linguistic elements. As they are the two recent President of the United States, their policy as well as their speech plays a big role in shaping the immigrant discourse. The aim of this study is to understand the ideology behind Obama and Trump's speech about immigration. In order to do that, the study is going to answer the question of how they define immigrants in their speech. Simultaneously, it will also answer the question of how they place immigrant in the American society. To answer these questions, their speeches are going to be analyzed through the three-dimensional framework by Norman Fairclough. Using the threedimensional framework, the ideology can be understood by first analyzing the text. After that, its production and distribution in the political discourse will be seen through the notion of power relation. Finally, the relation between these speeches with the society will be seen through how they put immigrant in the American society.

\section{Literature Review}

\section{Critical Discourse Analysis}

Since it was first published, the framework of Critical Discourse Analysis (CDA) has been increasingly popular. Due to its rising popularity, there are some 'discourse analysis' works that are called as CDA, although arguably they might not be one. Paltridge (2008) defines 'discourse analysis' as "an approach to the analysis of language that looks at the patterns of language across text as well as the social and cultural context in which the texts occur". Meanwhile to distinguish between Critical Discourse Analysis and discourse analysis, Fairclough (1995) mentions three characteristics of CDA. First of all, CDA analyses not only the discourse of a text, but also its relationship with other elements in a social process. Secondly, CDA includes some form of systematic analysis to a text rather than just a general commentary of a discourse. Last but not least, CDA addresses social issue and their discursive aspects. As it is not only giving a general comment, it aims to mitigate these issues by also being a normative critique. Because of these characteristics, CDA can be used in analyzing the political dominance and ideology that are manifested in the social life and social form. 


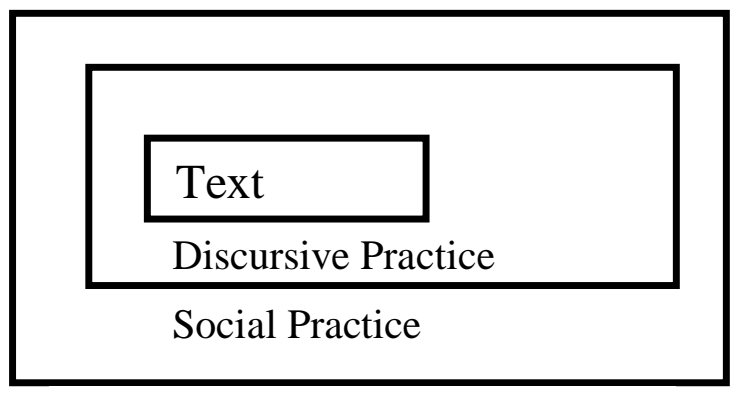

Figure 1. Fairclough's three-dimensional framework (1993)

Ideology has been a crucial part in the development of CDA by Fairclough. Faiclough (1995) sees ideology as a significant element of process in which the relation of power is established, maintained, enacted and transformed. He makes three claims about ideology and language. The first claim is that ideologies can be primarily located in the implicit or unsaid propositions of a text. Fairclough also see that ideology can be seen from the 'assumed knowledge' or the 'background knowledge' that is implicitly put in a text. The second one is that interaction and interpersonal meaning may be ideological. This is related to the widely discussed 'ideational meaning' from Halliday (1978) in which the content of the text is formed. Lastly, Fairclough claims that "the theorization of power as in part 'ideological/discoursal', the power to shape orders of discourse, to order discursive practices in dominance" (1995).

In his study, Fairclough uses a three-dimensional framework to analyze the relation between social practice and the political discourse. The three-dimensional framework starts with a text analysis. In the first dimension, Fairclough analyze the text regarding its grammatical structure as well as words used. In the second dimension, he relates the text with its discursive practice. This is related with the production, distribution, and consumption of the text, or as known as the context of the text. In this layer, the discourse of the text is really important, as it will show how the text contributes the whole discourse. The last dimension is what usually called as the social practice. It is related with the text and the discourse as a whole social practice. This also means that a Critical Discourse Analysis can only be 'critical' if it's related with the full social practice.

\section{Pejorative word choice, power-relation, and identity}

Fairclough (2011) states that "discursive practices may have major ideological effects". He argues that discursive practice helps shape power relation in the society through the ways in which they represent and position certain group of people. Because discursive practice possesses such a critical part in society, CDA aims to reveal the ways in which language is utilized in such practice. It analyzes everyday practices to find the abuse of power generally achieved under the guise of common-sense assumptions (Strauss and Feiz, 2014, p. 315). They claim that power structures are revealed, created and transferred or retained through language. In regard to immigration, Wodak (2016) sees that language is used to emphasize power relation. He conceptualizes it into the

CELTIC: A Journal of Culture, English Language Teaching, Literature \& Linguistics ISSN: 2356-0401, E-ISSN: 2621-9158, VOL. 6, NO. 2, December 2019. 
Politics of Fear, in which immigrants are targeted and used as scapegoat. The fear is constructed for the purpose of building the foundation for politicians to construct and identify themselves as saviors for these immigrants.

Individuals are never outside cultural forces or discursive practices but always 'subject' to them. Their identities are governed by a range of 'subject positions' ('ways of being'), approved by their community or culture, and made available to them by means of the particular discourses operating within a given social context. If people do not conform to these approved discourses in terms of how they speak, act and behave, they may be stigmatized by others with labels such as 'weird', 'a misfit', 'a freak' or 'an outsider'. The people who are stigmatized are usually powerless and they have to follow the convention. Meanwhile, those who are pressuring people to conform are usually in power, they have the privilege to create the convention. Language therefore acts as a regulatory force to press individuals to conform to socially approved patterns of speech and behavior.

The construction of identity is a process that involves power relation between the superordinate and the subordinate. In political discourse, it is important to see this power relation as political speech has its own power. Political speeches, usually spoken by those in power possess power to construct idea and identity. Moreover, political speech could also construct a group identity.

\section{METHOD}

This article uses qualitative as well as library research. The primary data is taken from Obama's and Trump's political speeches. There are five speeches from Obama and two speeches from Trump. The transcripts of the speeches are taken from the American Presidency Project ${ }^{i}$ by University of California, Santa Barbara. These speeches are chosen out of hundreds of political speeches that they delivered because the main topic of these speeches was immigration. It is important that the data only discussed immigration so that the ideology regarding the issue can be specifically highlighted. The speeches come from different settings, time, and audience in order to show how different contexts may affect the speeches differently. For the purpose of this article, the speeches are referred in codes. For Obama's speeches, they are referred as O1, O2, O3, O4, and O5. Whereas for Trump's speeches they are referred as T1 and T2. The details about these speeches are explained in the table below. 
Table 1. Details of the data; Obama's and Trump's political speeches.

\begin{tabular}{|c|c|c|}
\hline Code & Obama & Trump \\
\hline \multirow[t]{2}{*}{1} & April 3, 2006 & August 31, 2016 \\
\hline & $\begin{array}{l}\text { Floor Statement of } \\
\text { Senator Barack } \\
\text { Obama Immigration } \\
\text { Reform }\end{array}$ & $\begin{array}{l}\text { Trump-Pence Rally - } \\
\text { Pheonix, Arizona }\end{array}$ \\
\hline \multirow[t]{2}{*}{2} & May 4, 2006 & December 9, 2017 \\
\hline & $\begin{array}{l}\text { Immigration Rallies } \\
\text { and Status of } \\
\text { Reform - Podcast }\end{array}$ & $\begin{array}{l}\text { The President's } \\
\text { Weekly Address }\end{array}$ \\
\hline \multirow[t]{2}{*}{3} & November 22, 2014 & \\
\hline & $\begin{array}{l}\text { The President's } \\
\text { Weekly Address }\end{array}$ & \\
\hline \multirow[t]{2}{*}{4} & November 21, 2014 & \\
\hline & $\begin{array}{l}\text { Memorandum } \\
\text { Modernizing } \\
\text { Streamlining } \\
\text { United the } \\
\text { Immigrant States } \\
\text { System for the } 21 \mathrm{st} \\
\text { Century }\end{array}$ & \\
\hline \multirow[t]{2}{*}{5} & November 20, 2014 & \\
\hline & $\begin{array}{l}\text { Address to the } \\
\text { Nation } \\
\text { Immigration Reform }\end{array}$ & \\
\hline
\end{tabular}

These speeches are analyzed using Fairclough's (1993) three-dimensional framework; textual, discursive practice, and social practice. From the textual dimension, the word choice and the themes in the speeches are analyzed. The words or phrases that are being analyzed are pejorative words, which could reflect the president's attitude towards immigration. Moreover, the themes that are related with immigrants are analyzed to show how they identify immigrants. In the discursive practice dimension, the speeches are seen as products of political discourse. Because of that, it is assumed that the speeches possess power to construct the society. Last, the speeches are seen from the perspective of American society as a whole. Thus the answer to the question "Who are Americans?" can be defined by placing these speeches as part of the discourse of the American society. Finally, through these three dimensions of analysis, the ideology behind Obama's and Trump's political speeches can be understood. What's more, it will give a clear understanding about how immigrants, as a minority and powerless group, are positioned by the presidents. 


\section{RESULT}

This section explains about the textual analysis of Obama and Trump's political speeches. This includes ways in which Barack Obama and Donald Trump represent immigrants especially those who are undocumented. There are two major recurring patterns that can be seen from both presidents. The first is how they choose to define immigrants using certain pejorative words. The second is how they relate immigration with certain themes in the immigration discourse.

\section{Word Choice}

Because Barack Obama and Donald Trump come from two different political parties, it is commonly presumed that they would describe immigrants in contrasting manners. Surprisingly, both Obama and Trump actually address immigrants almost in a uniform manner. They mostly use pejorative words to modify and describe immigrants in their political speeches. Table 2 and table 3 show the pejorative words used by Obama and Trump when describing immigrants.

Table 2. Pejorative words or clauses used by Obama to describe immigrants from the data

\begin{tabular}{lc}
\hline Pejorative Words/ Phrases & Frequency \\
\hline Illegal immigrant(s) & 5 \\
Undocumented immigrant(s) & 13 \\
Undocumented alien & 1 \\
Undocumented population & 2 \\
Felon (felony), criminal & 7 \\
\hline
\end{tabular}

Table 3. Pejorative words or clauses used by Trump to describe immigrants from the data

\begin{tabular}{lc}
\hline Pejorative Words/Phrases & Frequency \\
\hline Illegal immigrant(s) & 16 \\
Criminal aliens & 13 \\
Lower skilled & 2 \\
Violent (criminals) & 3 \\
Gang members & 1 \\
Felon & 1 \\
\hline
\end{tabular}

From the tables above, it can be seen that both Obama and Trump refer to most immigrants as 'illegal immigrant(s)' in their speeches. Obama uses 'illegal immigrant(s)' five times in his five speeches, while Trump uses the term sixteen times in 
two speeches. In addition, Obama prefers to use the term 'undocumented immigrant(s)', as he uses the term more often. In contrast, Trump never use the term in his whole speech. He prefers to use the term 'illegal immigrants' rather than 'undocumented immigrants.' The term 'undocumented immigrant' is considered as politically correct, and this is the term that the immigrants preferred themselves. These findings suggest that although both have a similar attitude in seeing immigrants as "illegal", they have a different degree of tolerance. From their preference, it could also be argued that Obama and Trump see and identify immigrant differently. Obama prefers to identify immigrants as "undocumented", while Trump straight up sees immigrants as "illegal".

Another noticeable difference that can be seen from the tables is how Trump uses more adjective to descriptive immigrants than Obama. Trump mentions about the illegal immigrants being 'criminals', 'lower skilled', 'violent'. In his two speeches, Trump uses these terms to define immigrants. Meanwhile, Obama never really use any adjectives to describe the immigrants. In whole of his five speeches, never once Obama describes immigrants using negative adjectives. This suggests that while Obama still put some space when identifying immigrants in the American society, he does not have any personal negative judgment towards them. On the other hand, by using more adjectives, Trump can be seen as having more negative bias towards immigrants.

It is also interesting that while Obama and Trump mostly use negative pejorative when referring to immigrants, they also tend to describe American people using "negative" adjectives. Table 4 below shows the words used by Obama and Trump to describe American people.

Table 4. Words used to describe American in the data

\begin{tabular}{cc}
\hline Obama & Trump \\
\hline Poor & Innocent \\
Forgotten & Incredible \\
Welcoming & Vulnerable \\
Generous & Unemployed
\end{tabular}

The finding shows that the two presidents use pejorative words in a peculiar manner. Instead of using them to relate American people with negative representation, it is used to show how vulnerable the American society is because of immigration. From the table above, it can be seen that Obama uses the word 'poor' and 'forgotten' when describing the Americans. However, this is not referring to social status. In the sentence, Obama mentions Americans as 'poor' and 'forgotten' to show how the U.S. legislation is forgetting Americans. Obama said that "our conscience can't rest so long as 37 million Americans are poor and forgotten by their leaders in Washington and by the media elites" (Obama, 2007). This is quite similar with the way Obama refers to immigrants as 'hungry' to prove his point about immigrants needing their help. Meanwhile, Trump also describes Americans in a similar manner. He addresses them as 'vulnerable' and 
'unemployed', not to degrade American people, but to emphasize how undocumented immigrants are ruining their nation.

In short, while Obama and Trump use similar words to address immigrants, they still prefer using different terms. Obama prefers using the term "undocumented immigrants", while Trump prefers the term "illegal immigrants" or "illegal aliens". Interestingly, they also use negative description when referring to American. However, the negative description given to the American people is actually their strategy to differentiate between "immigrants" and "Americans"

\section{Theme}

In the United States of America, immigration is a complicated issue. It is complicated because immigration is related with other social problems that people believe comes along with the immigrants who come to America. In their speech, Obama and Trump relate immigration with several other themes.

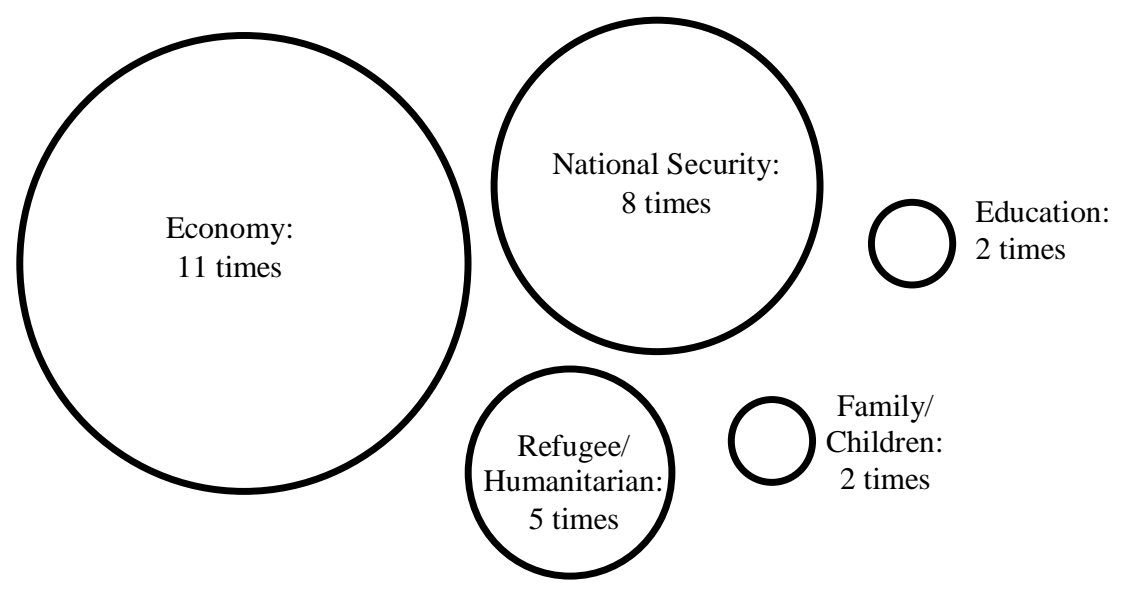

Figure 2. Obama's topic regarding immigration discourse from five political speeches

From the five speeches that have been analyzed, Obama relates immigration with six other themes: economy, national security, refugee/humanitarian, family/children, and education. Figure 2 depicts the proportion of issues that are related with immigration in five of Obama's speeches. The most talked about theme is economy. In his speech, Obama talks about how immigration is affecting as well as being affected by the American economy as much as 11 times. Another theme that is discussed quite a few times is national security. The issue of national security is usually related with how a lot of undocumented immigrants are criminals. He also talks about immigration as a humanitarian issue. This is because he sees that a lot of immigrants who come to the USA are refugees. Two other themes that are also discussed, although not much, are family/children and education. Obama talks about how the immigration system is unfair to the children who are born in the USA while their parents are immigrants. Regarding education, Obama states that most of the people who have $\mathrm{PhD}$ in America are 
immigrants. This means that immigrants actually play a huge role in the American education.

Similar to Obama, Trump also relates immigration with other themes in the United States of America. However, he only relates immigration with four other themes.

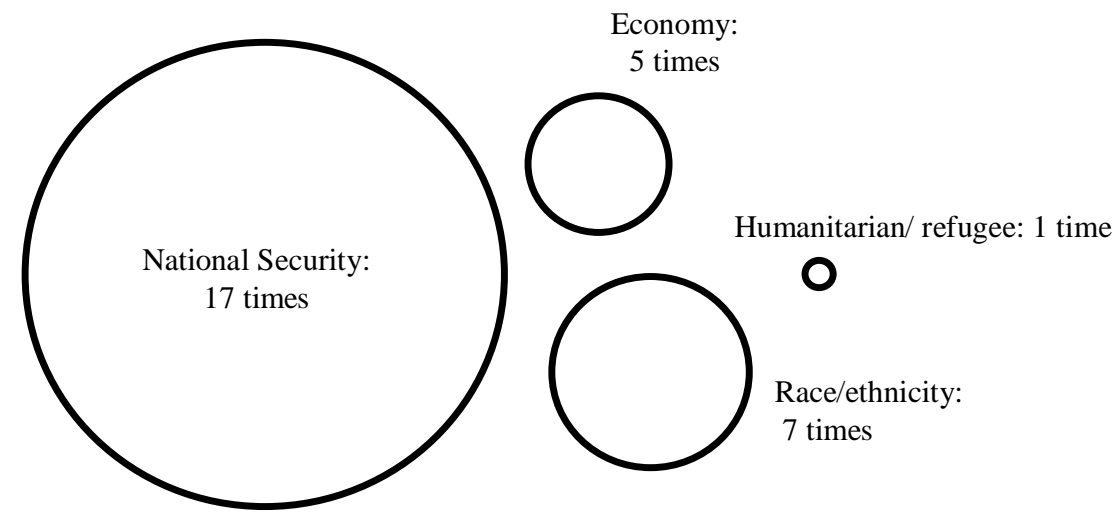

Figure 3. Trump's topic in immigration discourse

As can be seen from figure 3, the main theme that Trump discussed when talking about immigration is national security. In the speeches that are being analyzed, Trump talks about how immigrants could jeopardize the safety of Americans 17 times. He sees illegal immigrants as criminals. Trump also talks about race and ethnicity. This topic is discussed for 7 times in his speeches. He relates immigration and race and ethnicity by mentioning about Latino and African-Americans. Surprisingly, he only talks about immigration and its effect on American economy five times. The very least topic that Trump discusses is immigration and refugee. He says that he will not let America becomes like Europe by allowing every refugee in.

In short, a quite significant difference can be seen in the themes discussed by Obama and Trump. The main concern of Obama in the immigration discourse is its relationship with American economy. The second most talked about theme in his speech is national security. While he only mentions about humanitarian/refugee five times in the speeches, it is still a quite prominent topic. On the other hand, Trump's priority when talking about immigration is, surprisingly, national security. Unlike Obama, Trump is more concern with the national security rather than economy when it comes to immigrants. Still, Trump is also concerned with the economy by addressing the issue five times. Perhaps the least unsurprising result is how Trump only speak about humanitarian/refugee once in whole of his speeches.

\section{DISCUSSION}

\section{Power Relation}

The use pejorative word choice and the theme that is being related with immigration in Obama and Trump's speeches are suggesting superiority over immigrants. In Obama's speeches, this notion is explicitly stated. Some of the words that 
he uses suggest that he sees immigrants as a problem for America. The immigrants are seen as a marginal group as they don't have any legal right in America. An example can be drawn from $\mathrm{O} 2$ where Obama is concerned with how illegal immigrants are being taken advantages of.

"On the other hand, to those who are fearful of these immigrants, in some cases because they have come to represent a loss of control for the country and its borders, I would just say to them that we can't have a country in which you have a servant class that is picking our lettuce or plucking our chickens or looking after our children or mowing our lawns but who never have the full rights and obligations of citizenship." (Obama, 2006)

From this excerpt, Obama is showing how immigrants are powerless as they never "have the full rights and obligations of citizenship". The statement also shows the notion that Americans have power over the immigrants. Moreover, the speeches also create the idea that immigrants are always treated as the second-class group. However, there is also a statement from Obama about being a part of immigrant story in O1. Obama says that "like millions of Americans, the immigrant story is also his story." This statement is mitigating his superiority over the immigrants. He is showing that because he comes from a same background and thus understands the immigrants.

On the other hand, Trump uses pejorative word choice to the fullest as he is not afraid to admit that he hates immigrants. This unmitigated pejorative shows how Trump feels about himself, as a president, and about immigrants. In some of his statements, it can be seen that he looks down to immigrants.

“... this doesn't change the fact that most illegal immigrants are lower skilled workers with less education, who compete directly against vulnerable American workers, and that these illegal workers draw much more out from the system than they can ever possibly pay back.” (Trump, 2016)

His statement about illegal immigrants further supports the general assumption in American society about immigrants, as being the root of all their problems. Trump bluntly states that immigrants could never possibly pay them back. This statement suggests that immigrants are in debt to the American people. Clearly, those who are in debt are powerless to their debtor. It emphasizes that American people are superior to immigrants because immigrants "owe" them. Both Obama and Trump are claiming their superiority by stating that immigrants would never have what the American people have. This shows that the discourse of immigrants is heavily influenced by those who have power in politics and in law.

\section{Identity}

The result shows that Obama and Trump describe the immigrants' identity as 'anti-American'. This can be seen from how they choose to represent the idea of immigrants. Obama and Trump use pejorative words to describe immigrants. These words, coming from such significant figures could affect how the society defines immigrants, thus constructing the immigrant identity. Even though in general it could be argued that they have similar view towards immigrant identity, there are still a few differences in Obama and Trump's ideology about American identity. 
First of all, Obama sees America as a nation of immigrants. This ideology about America as a nation of immigrants is clearly stated in his speeches. In five speeches, he states that "America is a nation of immigrants" six times. He states this at least once in every speech. By mentioning this in his political speeches, Obama is trying to emphasize and remind America that they were in fact immigrants. Obama also say that America is colorful because of these immigrants. However, he still put some spaces between immigrants and American by stating that America is also a nation of law. For Obama, what is important in order to protect the American society is law. He sees that only those who abide the law may become a U.S. citizen. This shows that his ideology of American identity lies in the law.

Obama mentions that immigrants can become American citizen if they agree to go through several legal stages and abide the law. On November 2014, he mentions that those who have been living in America for more than five years, have American born children or legal residents, could passed the criminal background check, and are willing to pay taxes could stay in America temporarily without the fear of deportation. By saying this, Obama is showing how he, as the president of the United States, is opening opportunities for immigrants to become Americans. The reason behind this perhaps could be due to the fact that his parents were also immigrants from Kenya. Because of this, Obama is more open to the idea of accepting immigrants as a part of American society.

On the other hand, Trump does not have the desire to see immigrants as a part of American society at all. In fact, Trump is really against the amnesty system that is implemented by Obama. He says that he "will break the cycle of amnesty and illegal immigration. We will break the cycle. There will be no amnesty" (Trump, 2016). Trump also wishes to deport all of the immigrants. In addition to deporting immigrants, he also wishes to build border walls that will separate America and Mexico. This action suggests that he never identify immigrants as a part of American society. In fact, he even hates the fact that immigrants can become American citizen legally.

The notion of racial issue could clearly be seen from the beginning of Trump's speech. In his Arizona rally, he clearly mentioned Mexican president. He also said that the Mexican people "will pay for it". By stating this, he is suggesting that the Mexican people are at fault and because of that they need to pay for it. Interestingly, this also suggests the racial "power imbalance". By saying that Mexico is wrong, Trump is suggesting that Mexico is also less worthy than American. This could be seen as a "nationalism" issue. However, Trump also mentioned other thing, such as Hispanic, which showed that it was more about racial issue rather than nationalism. As most people would have noticed by now, most of Trump speeches are siding with Caucasian or White-American. Moreover, his supporters are 80\% comprised of White American. This further proves the point that Trump's is siding with one race rather than with American nationalism.

In short, the ideology behind Obama and Trump's political speeches lies in the identity of immigrants and Americans. In the early 20th century, the definition of American identity is closely related with White Anglo-Saxon Protestants or WASPs. According to Trump's ideology about the American identity, there is little to no shift

CELTIC: A Journal of Culture, English Language Teaching, Literature \& Linguistics ISSN: 2356-0401, E-ISSN: 2621-9158, VOL. 6, NO. 2, December 2019. 
from the WASPs. This ideology is perhaps influenced by his political party. As a part of the Republican Party, Trump is really conservative with the American identity. On the other hand, Obama is shifting the idea of American identity through his political speeches. He does not identify Americans as only WASPs. He sees the identity of America as a colorful nation. The only rule that everyone has to follow if they want to be American citizen is to abide the law.

\section{CONCLUSION}

The study shows that both Obama and Trump see immigration as a problem in America. It can be seen from how they describe immigrants. They choose words that have negative connotation when describing immigrants. On the other hand, they describe "Americans" using the opposite adjectives. This is what is called as "negative representation of others'. In political speech, negative representation of others is often used to contrast the minority from the majority. In addition, the theme that they choose when they talk about immigrants can also show how they see immigrants. When talking about immigrants, both presidents mention about national security and economy. This means that they see illegal immigrants as a threat the national security as well as American economy. The general image of immigrants that the two presidents are representing is immigrant as "Anti-American".

Looking at these, it can be seen that Obama and Trump's ideology regarding immigration lies on the notion of Americans and immigrant's identity. While Obama could identify immigrants as a part of American society, Trump never sees immigrants as a part of the American society. The reason lies not only behind their political parties, but also behind their racial identity. Obama, as a Democrat, leans towards centralist view. This could be seen from how they mitigate the identity of Americans while at the same time maintain the national identity. On the other hand, Trump is a republican. Republican Party is known to have a right-wing view in the politics. They are fundamentalist and conservatives. Obama and Trump racial identity might also play a huge role in their ideology. As Obama comes from a minority race, he could relate to the immigrants' discourse as minority. Meanwhile, Trump as a White-American never experience being a minority.

Although the ideology of immigration could be seen from their speeches alone, a further study regarding immigration and ideology should be seen from the policy as well. The policy could show how the presidents take actions on immigration, not only from their words but from their actions as well. A throughout analysis of Obama and Trump could also uses data from different time and different occasion. Seeing how they represent immigration in a non-formal context could also shine more light into their values regarding immigration. Moreover, this article only discusses the immigration discourse through the perspective of people in power. In the future, a deeper study can be conducted to see immigration from the voice of immigrants. Perhaps by understanding the discourse though the eyes of the minority, there could be more understanding of why such identity is always bestowed upon them. 


\section{REFERENCES}

Baxter, J. (2016). Positioning language and identity. The Routledge Handbook of Language and Identity. Routledge. https://www.routledgehandbooks.com/doi/10.4324/9781315669816.ch2 Accessed on: 17-12-2018.

Biria, R. \& Mohammadi, A. (2012) The socio pragmatic functions of inaugural speech: A critical discourse analysis approach. Journal of Pragmatics Vol. 44 p.1290-1302. Elsevier

Boyd, M. S. (2009). De-constructing race and identity in US presidential discourse: Barack Obama's speech on race. ATLANTIS: Journal of the Spanish Association of Anglo-American Studies. Vol. 31 No.2. URL: https://www.jstor.org/stable/41055365 Accessed: 11-09-2018

Fairclough, N. (2010). Critical discourse analysis: the critical study of language. (Second Edition). London, United Kingdom: Routledge.

Fairclough, N. \& Wodak, R. (1997) Critical Discourse Analysis, in T. van Dijk (ed.) Discourse as Social Interaction, pp. 258-84. London: SAGE.

Feng, H. \& Liu, Y. (2010) Analysis of Interpersonal Meaning in Public Speeches-A Case Study of Obama's Speech. Journal of Language Teaching and Research, Vol. 1, No. 6, pp. 825-829. doi:10.4304/jltr.1.6.825-829

Fur, G. (2014). Indians and immigrants-entangled histories. (Unkown)

Gold, S. J. (2009) Immigration Benefits America. Springer Science \& Business Media 46:408-411. DOI 10.1007/s12115-009-9235-4

Halliday, M. A. K. (1970) Functional diversity in language as seen from a consideration of modality and mood in English. Foundations of Language, Vol. 6, No. 3. Springer. https://www.jstor.org/stable/25000463. Accessed: 11-09-2018.

Halliday, M. A. K. \& Matthiessen, C. M. I. M. (2014) Halliday's introduction to functional

grammar. (Fourth Edition). London, United Kingdom: Routledge.

Hao, L. (2007). Color Lines, Country Lines: Race, Immigration, and Wealth Stratification in America. New York: Russell Sage Foundation.

Higham, John. (1984). Send These to Me: Immigrants in Urban America. Rev. ed. Baltimore: John Hopkins University Press

Hirschman, C. (2010). The impact of immigration on American society: looking backward to the future. The Institute for Human Sciences (IWM), Vienna. http://www.iwm.at/transit/transit-online/the-impact-of-immigration-onamerican-society/

Huen, K. L. B. (2011). Text analysis with a systemic functional approach: Analysing US presidential inaugural address (Outstanding Academic Papers by Students (OAPS)). Retrieved from City University of Hong Kong, CityU Institutional Repository. http://hdl.handle.net/2031/6452 
Krampa, A. \& Sarfo, E. (2013). Language at War: A Critical Discourse Analysis of Speeches of Bush and Obama on Terrorism. International J. Soc. Sci. \& Education Vol. 3-2

Lazarus, Emma. (1883). The New Colossus. Statue of Liberty, New York, New York.

Quinonez, E. S. (2018) (Un)welcome to America: a critical discourse analysis of anti-immigrant rhetoric in Trump's speeches and conservative mainstream media. Electronic Theses, Projects, and Dissertations. 635. http://scholarworks.lib.csusb.edu/etd/635

Sarbast, D. (2017). Make America great again: a rhetorical discourse analysis of Donald Trump's immigration speech. Faculty of Culture and Society Department of Global Political Studies International Migration and Ethnic Relations.

Schlesinger, Arthur, Jr. (1971) The History of American Presidential Elections, 17891968. New York: Chelsea House Publisher.

United States. Department of Homeland Security. (2017). Yearbook of immigration statistics: 2016. Washington, D.C.: U.S. Department of Homeland Security, Office of Immigration Statistics. http://www.ntis.gov

US Legal, Inc. (2016). Immigration Law and Legal Definition. Retrieved January 4, 2019, from https://definitions.uslegal.com/i/immigration/

Wang, J. (2010) A Critical Discourse Analysis of Barack Obama's Speeches. Journal of Language Teaching and Research, Vol. 1, No. 3, pp. 254-261. doi:10.4304/jltr.1.3.254-261.

Weisberger, B. A. (February/March 1994) A Nation Of Immigrants. American Heritage, Volume 45, Issue 1. https://www.americanheritage.com/content/nation-immigrants Accessed: 09-01-2019.

\footnotetext{
'See: http://presidency.proxied.Isit.ucsb.edu/
} 